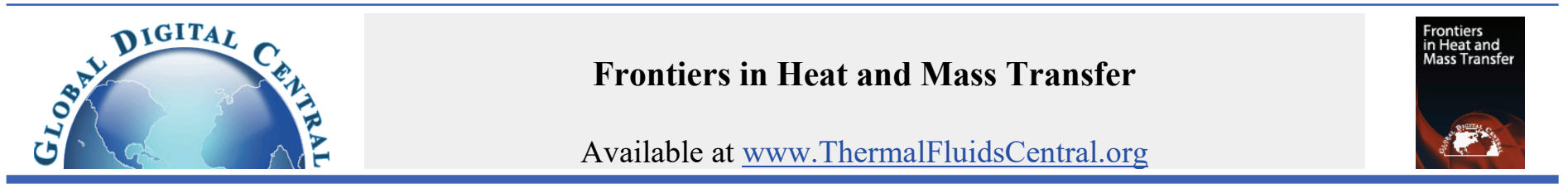

\title{
MEASUREMENTS AND MODELING OF FLUID FLOW AND THERMAL PROCESSES IN AN INDUSTRIAL PRECALCINER
}

\author{
Qingxin $\mathrm{Ba}^{\mathrm{a}}$, Scott Egbert ${ }^{\mathrm{b}}$, Xuefang $\mathrm{Li}^{\mathrm{a}}{ }^{\mathrm{a}}$, Lin Cheng ${ }^{\mathrm{a}, * *}$ \\ ${ }^{a}$ Institute of Thermal Science and Technology, Shandong University, Jinan, Shandong, 250061, China \\ ${ }^{b}$ Department of Mechanical Engineering, Brigham Young University, Provo, Utah, USA
}

\begin{abstract}
Precalciner performance is crucial to the production rate and lifespan of cement kiln systems. The gas-solid flow and pulverized coal combustion processes in an industrial precalciner were numerically modeled to understand the flow patterns and thermal processes in the system. The gas and meal flow rates and properties were measured on-site to determine the boundary conditions for the simulations and to validate the models. The upward swirl of the gas flow in the furnace helped disperse the particles and extend their duration in the precalciner. The $\mathrm{O}_{2}$ and $\mathrm{CO}_{2}$ concentration distributions indicated that the coal particles were well dispersed and fully combusted. The calculations showed that the precalciner outlet temperature was too high which reduces the thermal efficiency and may damage the preheater installed just after the precalciner. Finally, an optimized precalciner was proposed to improve the temperature distribution. The present work can be used for improving the design of industrial precalciners.
\end{abstract}

Keywords: two-phase flow, combustion, numerical simulation, on-site measurements

\section{INTRODUCTION}

In modern cement production, a precalciner significantly shortens the rotary kiln length and improves the fuel efficiency. Precalciners also allow for increased production rates and extended system lifespans. A precalciner transfers the decomposition of the raw cement meal from the accumulation state in the rotary kiln to the suspension state in the precalciner (Dou et al., 2007). The precalciner is installed between the suspension preheater and the rotary kiln for fuel combustion and calcium carbonate decomposition (Dou et al., 2007; Boesch et al., 2009). The processes taking place in the precalciner are very complex, and include gas-solid two-phase flows, coal combustion and raw material decomposition (Liu et al., 1995; Fan et al., 2014). These flow and physico-thermal processes need to be well understood to increase production rates and reduce energy use.

Many numerical studies have been presented to model the complex fluid flow and thermal processes in precalciners. Mass and energy balances have been computed using both one-dimensional (Rosemann, 1986; Kolyfetis and Vayenas, 1988; Iliuta et al., 2002; Dam, 2002) and two-dimensional models (Liu et al., 2004). However, because of the simplifications in these reduced geometries, they are not able to account for the non-uniform gas and solid phase flows, so they can only provide general insights into the actual precalciner behavior. The hydrodynamics of the precalciner gas-solid two-phase flow has also been simulated in three-dimensions using a two-fluid model with granular flow kinetic theory (Zheng, Lu et al., 2005; Zheng, Liu et al., 2005; Hu et al., 2006). The instantaneous velocity and particle distributions were used to represent the transport properties of the flue gas and the raw meal. The particle distributions and gas velocities showed that the gas-solid flow was significantly influenced by the primary air jet velocity and by the throat orientation in a dual combustion and denitration process precalciner (DD precalciner) (Zheng, Lu et al., 2005). While these insights are useful for informing precalciner design, existing studies often neglect the coal combustion which generates the heat for the raw meal decomposition.

The combustion processes in industrial furnaces have been studied by other workers (Ma et al., 2016; Qi et al., 2017; Zhang et al., 2018). Pulverized coal combustion in industrial furnaces can be divided into the high temperature pyrolysis, volatile combustion and burn out stages (Bashir et al., 2004). The heating rate and coal pyrolysis depend on the sizes of the coal particles and the heat source (Veras et al., 1999; Gentzis et al., 1996). Fidaros et al. (2007) calculated the velocity, temperature and concentration distributions of the reacting coal particles in a cylindrical precalciner, but did not take into account the influence of the tertiary air, leading to inaccuracies in the calculated flow fields. Huang et al. (2006) and Mei et al. (2017) numerically modeled the flow fields and thermal processes in a swirl-spray precalciner as well as a vortexing precalciner. The tertiary air and flue gas streamlines, particle tracks and combustion characteristics were used to analyze the complete flow behavior in the precalciner. However, the DD precalciner geometry with a tertiary air inlet and a middle neck differs from these other precalciners, which leads to different internal flow and combustion characteristics. Moreover, many of the existing studies have been limited to numerical simulations and engineering models without measurements of the flow fields in actual precalciners. The numerical models are commonly based on design parameters rather than measurements. Experimental studies have been limited to bench scale tests (Lv et al., 2011; Kupper and Tiggesbaeumker, 1983), with few industrial scale measurements.

In this paper, the flow parameters, gas compositions and meal properties were measured on-site in an industrial cement production line in Shandong Province, China. The measurements were then used to build a three-dimensional full scale numerical model of the DD precalciner. The gas flow, pulverized coal particle and raw meal movements, along with the coal combustion characteristics, were then predicted with the

\footnotetext{
* Corresponding author. Email: lixf@sdu.edu.cn

** Corresponding author. Email: cheng@sdu.edu.cn
} 
results were compared with the measurement data. The tertiary air and flue gas flow characteristics, the solid trajectories, the coal-combustion mechanism and the thermal field were predicted and analyzed to provide guidance for optimizing the precalciners.

\section{MEASUREMENTS}

\subsection{Experimental System}

Measurements were taken on the precalciner in a $2500 \mathrm{t} / \mathrm{d}$ cement production line shown in Fig. 1. The experimental system and five monitoring positions are shown in Fig. 2. The solid line shows the gas flow direction while the dashed line shows the production material flow direction. The gases include the flue gas, tertiary gas and coal spreading air. The flue gas from the rotary kiln entered the precalciner bottom inlet, where it mixed with the preheated tertiary air from the grate cooler and the coal spreading air. Pulverized coal particles were sprayed with the coal spreading air into the precalciner. The coal particles were heated by the flue gas and tertiary air mixture before burning. The raw meal was brought into the precalciner on the other side after four preheating stages. The raw meal was further heated by the flue gas and coal combustion to accelerate decomposition before the gaseous and solid reaction products flowed into the fifth preheater. The gas stream then continued to flow into the earlier preheaters to heat the raw meal, while the solids entered the rotary kiln to be calcined to produce cement clinker.

Five monitoring positions were used as shown in Fig. 2 to measure the operating parameters and boundary conditions between each stage. The specific parameters measured at each point and the measuring equipment are listed in Table 1 with the accuracies listed in Table 2. Monitoring points 1, 2 and 3 were used to measure the tertiary air, coal spreading air and flue gas to get the gas conditions at each inlet. The gas temperatures were measured using the flue gas analyzer or platinum rhodium-platinum thermocouple. The tertiary air pressure was measured with an $\mathrm{S}$ type pitot tube and a digital pressure gauge. The flue gas and coal spreading air pressures were measured using a multipurpose smoke tester. The smoke tester was also used to measure the gas flow rates and velocities. Since the flue gas was mixed with gaseous calcination products from the rotary kiln, the flue gas analyzer was used to measure the composition at point 3 . The solid phase inlet conditions of the pulverized coal and raw meal were monitored at point 2 and point 4 using a Schenck scale. The precalciner exit conditions were measured at point 5 using the flue gas analyzer for temperature and the multipurpose smoke tester for pressure. The raw meal and pulverized coal were sampled to determine the densities and average particle diameters. Proximate and ultimate analyses were carried out to determine the composition of the pulverized coal.

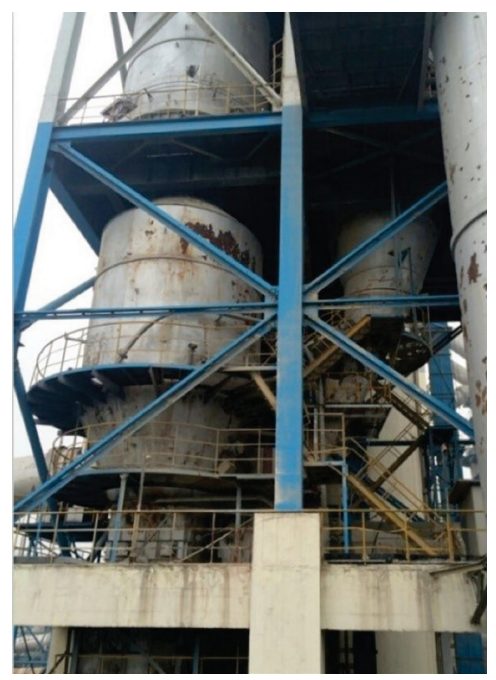

Fig. 1 Precalciner

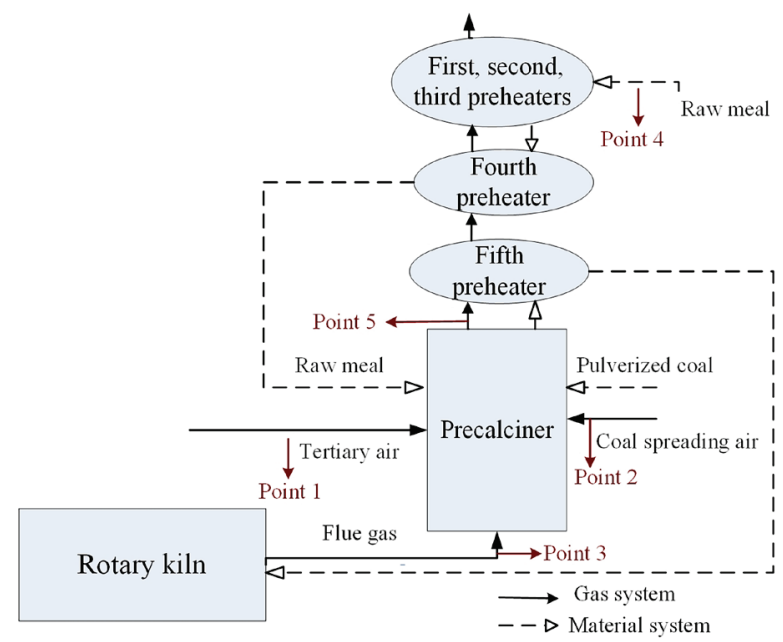

Fig. 2 Schematic of the experimental system

Table 1 Measurements

\begin{tabular}{|c|c|c|}
\hline Location & Parameters & Apparatus \\
\hline \multirow{3}{*}{ Point 1} & Temperature of tertiary air & $\begin{array}{l}\text { Platinum rhodium- } \\
\text { platinum thermocouple }\end{array}$ \\
\hline & $\begin{array}{l}\text { Velocity, and flow rate of } \\
\text { tertiary air }\end{array}$ & $\begin{array}{l}\text { Multipurpose smoke } \\
\text { tester }(3012 \mathrm{H})\end{array}$ \\
\hline & Pressure of tertiary air & $\begin{array}{l}\text { Digital pressure gauge, } \\
\text { S type pitot tube }\end{array}$ \\
\hline \multirow{3}{*}{ Point 2} & $\begin{array}{l}\text { Temperature of coal spreading } \\
\text { air }\end{array}$ & $\begin{array}{l}\text { Flue gas analyzer } \\
\text { (Testo 350) }\end{array}$ \\
\hline & $\begin{array}{l}\text { Velocity, flow rate, and } \\
\text { pressure of coal spreading air }\end{array}$ & $\begin{array}{ll}\text { Multipurpose } & \text { smoke } \\
\text { tester }(3012 \mathrm{H}) & \\
\end{array}$ \\
\hline & Flow of pulverized coal & Schenck scale \\
\hline \multirow{2}{*}{ Point 3} & $\begin{array}{l}\text { Temperature and composition } \\
\text { of flue gas. }\end{array}$ & Flue gas analyzer \\
\hline & $\begin{array}{l}\text { Velocity, flow rate, and } \\
\text { pressure of flue gas }\end{array}$ & $\begin{array}{l}\text { Multipurpose smoke } \\
\text { tester }\end{array}$ \\
\hline Point 4 & Flow rate of raw meal & Schenck scale \\
\hline \multirow[b]{2}{*}{ Point 5} & Outlet temperature & Flue gas analyzer \\
\hline & Outlet pressure & $\begin{array}{l}\text { Multipurpose smoke } \\
\text { tester }\end{array}$ \\
\hline
\end{tabular}

Table 2 Measurement accuracies

\begin{tabular}{|c|c|}
\hline Measurement & Accuracy \\
\hline $\begin{array}{c}\text { Platinum rhodium- } \\
\text { platinum thermocouple }\end{array}$ & $\pm 1.5^{\circ} \mathrm{C}$ \\
\hline $\begin{array}{c}\text { Multipurpose smoke } \\
\text { tester }\end{array}$ & $\begin{array}{c}\text { Velocity } 5 \% \text { flow rate } 2.5 \% \text {; pressure } \\
2 \%\end{array}$ \\
\hline Digital pressure gauge & $0.1 \%$ \\
\hline S type pitot tube & $4 \%$ \\
\hline Flue gas analyzer & $\begin{array}{c}\text { Temperature } \pm 1{ }^{\circ} \mathrm{C} ; \text { concentration } 0.2 \% \\
\text { (oxygen) }, 5 \% \text { (other gases) }\end{array}$ \\
\hline Schenck scale & $1 \%$ \\
\hline
\end{tabular}

\subsection{Measurement Results}

The measured parameters are listed in Tables 3 to 7. The material parameters in Table 3 are used to calculate the gas-solid two-phase flow field. The flue gas composition is shown in Table 4. The proximate and ultimate analyses of the coal are listed in Tables 5 and 6 . The coal chemical composition is required to model the combustion in the precalciner.

The gas flow temperature, volumetric flow rate and velocity in Table 7 were used as the inlet boundary conditions for the simulations. 
The precalciner outlet pressure was used as the outlet boundary condition. In addition to providing the boundary conditions for the simulations, the measured pressures in Table 7 were also used to validate the models. The actual volumetric flow rates in Table $7, q_{\mathrm{v}}$, were calculated with the ideal gas assumptions.

$$
q_{v}=\frac{q_{v n} p_{n} T}{p T_{n}}
$$

where $q_{\mathrm{vn}}$ is the volumetric flow rate at standard conditions which was directly measured. $p_{\mathrm{n}}$ and $T_{\mathrm{n}}$ are the pressure and temperature at standard conditions, $101325 \mathrm{~Pa}$ and $273.15 \mathrm{~K} . p$ and $T$ are the actual pressure and temperature.

Table 3 Materials

\begin{tabular}{|c|c|c|c|}
\hline & $\begin{array}{c}\text { Density } \\
\left(\mathrm{kgm}^{-3}\right)\end{array}$ & $\begin{array}{c}\text { Average } \\
\text { diameter }(\mu \mathrm{m})\end{array}$ & $\begin{array}{c}\text { Mass flow } \\
\text { rate }\left(\mathrm{kgh}^{-1}\right)\end{array}$ \\
\hline Raw meal & 1051 & 80 & 165000 \\
\hline Pulverized coal & 930 & 80 & 7500 \\
\hline
\end{tabular}

Table 4 Flue gas composition

\begin{tabular}{|c|c|c|c|c|c|}
\hline Composition & $\mathrm{O}_{2}$ & $\mathrm{CO}$ & $\mathrm{NO}$ & $\mathrm{N}_{2}$ & $\mathrm{CO}_{2}$ \\
\hline Volume fraction (\%) & 2.880 & 0.040 & 0.114 & 73.280 & 23.686 \\
\hline
\end{tabular}

Table 5 Pulverized coal proximate analysis

\begin{tabular}{|c|c|c|c|c|c|c|}
\hline Ingredient & $M_{a d}$ & $V_{a d}$ & $A_{a d}$ & $F C_{a d}$ & $S O_{3}$ & $\begin{array}{c}Q_{n e t, a r} \\
\left(\mathrm{~kJ} \cdot \mathrm{kg}^{-1}\right)\end{array}$ \\
\hline $\begin{array}{c}\text { Mass } \\
\text { fraction } \\
(\%)\end{array}$ & 5.37 & 30.40 & 12.92 & 51.31 & 0.48 & 25732 \\
\hline
\end{tabular}

Table 6 Pulverized coal ultimate analysis

\begin{tabular}{|c|c|c|c|c|c|}
\hline Element & $C$ & $H$ & $O$ & $N$ & $S$ \\
\hline Mass fraction (ad) (\%) & 53.08 & 3.10 & 11.17 & 1.01 & - \\
\hline Mass fraction (daf) (\%) & 77.65 & 4.53 & 16.34 & 1.48 & - \\
\hline
\end{tabular}

Table 7 Gas flow parameters

\begin{tabular}{|c|c|c|c|c|c|}
\hline & Temperature $(\mathrm{K})$ & Standard flow rate $\left(\mathrm{Nm}^{3} \mathrm{~h}^{-1}\right)$ & Actual flow rate $\left(\mathrm{m}^{3} \mathrm{~h}^{-1}\right)$ & Velocity $\left(\mathrm{ms}^{-1}\right)$ & Gauge pressure $(\mathrm{Pa})$ \\
\hline Flue gas & 1350 & 27042.9 & 127162.5 & 15 & -350 \\
\hline Coal spreading air & 311 & 5514.9 & 5917.6 & 15 & -450 \\
\hline Tertiary air & 1190 & 69134.8 & 282600.0 & 25 & -650 \\
\hline Precalciner outlet & 1320 & & & & -900 \\
\hline
\end{tabular}

\section{COMPUTATIONAL FLUID DYNAMIC MODEL}

\subsection{Geometry and Meshing}

The DD precalciner model geometry is shown in Fig. 3. This geometry was based on the previously mentioned Shandong industrial precalciner and used for the computational fluid dynamic (CFD) calculations performed in this work. The cylinder diameter was $5.20 \mathrm{~m}$ and the middle neck diameter was $3.14 \mathrm{~m}$. The total height was $24.45 \mathrm{~m}$. The raw meal inlet was $6.67 \mathrm{~m}$ above the bottom with an inner diameter of $0.90 \mathrm{~m}$. The tertiary air inlet was $3.40 \mathrm{~m}$ above the bottom and $0.72 \mathrm{~m}$ from axis with an inner diameter of $2.00 \mathrm{~m}$. There are five inlets for pulverized coal with inner diameters of $0.18 \mathrm{~m}$ for inlets a-d and $0.10 \mathrm{~m}$ for inlet e. The coal spreading air entered the precalciner through pulverized coal inlets a-e. The flue gas inlet located at the bottom had a diameter of $1.73 \mathrm{~m}$. The precalciner outlet diameter was $3.14 \mathrm{~m}$.

The computational domain was discretized into tetrahedral elements using ANSYS ICEM. The mesh independence computations used meshes with 5.7, 7.8, 11.0, 13.5 and 16.6 million. The average outlet velocities are compared in Fig. 4. The calculated results were almost identical for grids with more than 11.0 million elements. Therefore, the geometry was calculated using an 11.0 million element mesh to minimize the processing time.

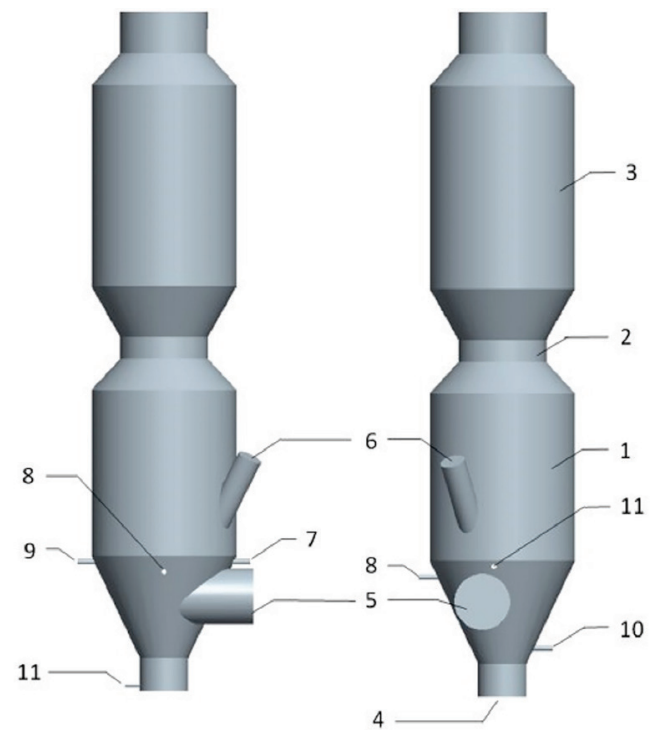

(a) Front view and right view
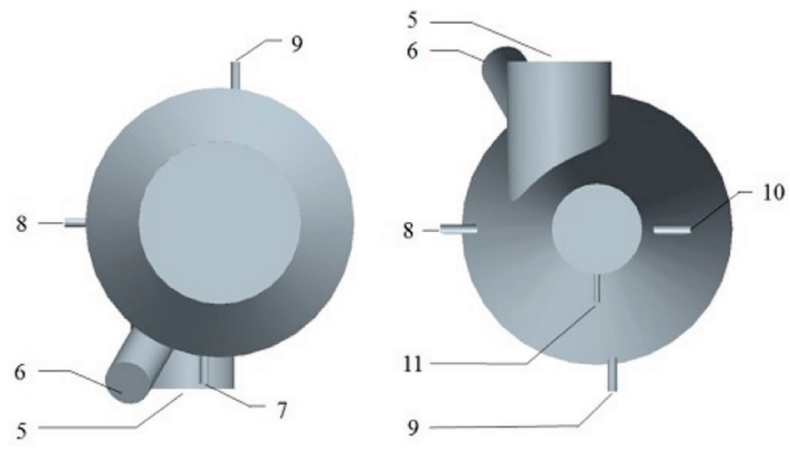

(b) Top view and upward view

Fig. 3 Geometry

(1 lower portion; 2 middle neck; 3 upper portion; 4 flue gas inlet; 5 tertiary air inlet; 6 raw meal inlet; 7 -11 pulverized coal inlets a-e.) 


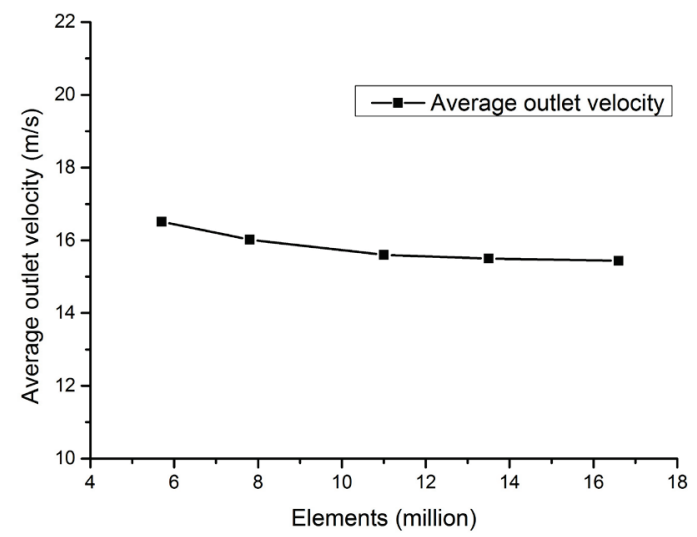

Fig. 4 Average outlet velocities with different numbers of elements

\subsection{Mathematical Models}

The renormalization-group (RNG) k- $\varepsilon$ model with the standard wall function was used to model the turbulence. The solid phase included raw meal particles and pulverized coal. The discrete phase model (DPM) was used for modeling the gas-solid two-phase flow field since the solid phase volume fraction was much less than $10 \%$. The non-premixed combustion model with a probability density function (PDF) was used to model the pulverized coal combustion.

\subsubsection{Turbulence model}

The transport equations for the turbulence kinetic energy, $k$, and its rate of dissipation, $\varepsilon$, in the RNG k- $\varepsilon$ model are

$$
\begin{aligned}
& \frac{\partial}{\partial t}(\rho k)+\frac{\partial}{\partial x_{i}}\left(\rho k u_{i}\right)=\frac{\partial}{\partial x_{j}}\left(a_{k} \mu_{e f f} \frac{\partial k}{\partial x_{j}}\right)+G_{k}+G_{b}-\rho \varepsilon-Y_{M} \\
& \frac{\partial}{\partial t}(\rho \varepsilon)+\frac{\partial}{\partial x_{i}}\left(\rho \varepsilon u_{i}\right)=\frac{\partial}{\partial x_{j}}\left(a_{\varepsilon} \mu_{e f f} \frac{\partial \varepsilon}{\partial x_{j}}\right)+C_{1 \varepsilon} \frac{\varepsilon}{k}\left(G_{k}+C_{3 \varepsilon} G_{b}\right) \\
& -C_{2 \varepsilon} \rho \frac{\varepsilon^{2}}{k}-R_{\varepsilon}
\end{aligned}
$$

where

$$
G_{k}=-\rho \overline{u_{i}^{\prime} u_{j}^{\prime}} \frac{\partial u_{j}}{\partial x_{i}}, \quad G_{b}=-\frac{1}{\rho}\left(\frac{\partial \rho}{\partial T}\right)_{p} g_{i} \frac{\mu_{t}}{P r_{t}} \frac{\partial T}{\partial x_{i}}, \quad Y_{M}=\frac{2 \rho \varepsilon k}{a^{2}}
$$

where $G_{k}$ and $G_{b}$ represent the dissipation of kinetic energy as turbulence due to the mean velocity gradients and buoyancy. $Y_{M}$ represents the contribution of the fluctuating dilatation in compressible turbulence to the overall dissipation rate. $a_{k}$ and $a_{\varepsilon}$ are the inverse effective Prandtl numbers for $k$ and $\varepsilon$. The constants $C_{1 \varepsilon}, C_{2 \varepsilon}$ and $C_{3 \varepsilon}$ have the following default values (Orszag et al., 1993): $C_{1 \varepsilon}=1.42, C_{2 \varepsilon}=1.68$ and $C_{3 \varepsilon}$ $=\tanh |v / u|$, where $v$ is the component of the flow velocity parallel to the gravitational vector and $u$ is the component of the flow velocity perpendicular to the gravitational vector. $g_{i}$ is the component of the gravitational vector in the $i$ th direction. $a$ is the speed of sound.

\subsubsection{Discrete phase model}

In the DPM, the fluid phase is treated as a continuum by solving the Navier-Stokes equations, while the dispersed phase is solved by tracking a large number of particles. The particles can exchange momentum, mass, and energy with the fluid phase. The DPM predicts the trajectory of a discrete phase particle by integrating the force balance on the particle, which is written as

$$
\frac{d \vec{u}_{p}}{d t}=F_{D}\left(\vec{u}-\vec{u}_{p}\right)+\frac{\vec{g}\left(\rho_{p}-\rho\right)}{\rho_{p}}+\vec{F}
$$

where $\vec{u}$ and $\vec{u} p$ are the fluid phase and particle velocities and $\rho$ and $\rho_{p}$ are the fluid and particle densities. $F_{D}(\vec{u}-\vec{u} p)$ is the drag force per unit particle mass and $\vec{F}$ is an additional acceleration (force/unit particle mass) term.

\subsubsection{Combustion model}

In the non-premixed combustion model, the instantaneous thermochemical state of the fluid is related to a conserved scalar quantity known as the mixture fraction, $f$. The mixture fraction can be written as (Sivathanu and Faeth, 1990)

$$
f=\frac{Z_{i}-Z_{i, o x}}{Z_{i, f u e l}-Z_{i, o x}}
$$

where $Z_{i}$ is the elemental mass fraction for element $i$. The subscripts $o x$ and fuel denote the value at the oxidizer stream inlet and the value at the fuel stream inlet.

For turbulent flows, the species equations can be reduced to a single equation for the mixture fraction assuming equal diffusivities. The Favre mean (density-averaged) mixture fraction equation is

$$
\frac{\partial}{\partial t}(\rho \bar{f})+\nabla \cdot(\rho \vec{v} \bar{f})=\nabla \cdot\left(\frac{\mu_{l}+\mu_{t}}{\sigma_{t}} \nabla \bar{f}\right)+S_{m}
$$

where $\mu_{l}$ and $\mu_{t}$ are the laminar viscosity and the turbulent viscosity. The source term, $S_{m}$, is due to the mass transfer into the gas phase from reacting coal particles. The constant $\sigma_{t}$ is 0.85 .

The Probability Density Function, $p(f)$, can be thought of as the fraction of time that the fluid spends in the vicinity of state $f$

$$
p(f)=\lim _{T \rightarrow \infty} \frac{1}{T} \sum_{i} \tau_{i}
$$

where $T$ is the time scale and $\tau_{i}$ is the amount of time that $f$ spends in the $\Delta f$ band.

The P-1 model was used to model the radiant heat transfer. The radiation flux, $q_{r}$, is

$$
q_{r}=-\frac{1}{3\left(a+\sigma_{s}\right)-C \sigma_{s}} \nabla G
$$

where $a$ is the absorption coefficient, $\sigma_{S}$ is the scattering coefficient, $G$ is the incident radiation, and $C$ is the linear-anisotropic phase function coefficient.

\subsection{Model Settings and Validation}

The pressure based solver was used for the calculations. The RNG k- $\varepsilon$ model with the standard wall functions was used to model the turbulence, the DPM was used to model the gas-solid two-phase flow field and the PDF model was used to model the pulverized coal combustion. The dual match rate model was used for the coal pyrolysis, the kinetic/diffusion controlled reaction rate model was used for the coke burnout, and the P1 model was used for the radiation. The pressure-velocity coupling used the SIMPLE algorithm. The gas boundary conditions were velocity inlets and pressure outlets. The discrete phase model boundary conditions were defined as "escape" at the inlets and outlets and as "reflect" on the walls.

The calculated and measured data are compared in Table 8 to validate the models. The pressure drops were approximately $14 \%$ less than the measured values and the outlet temperature was approximately $17 \%$ higher than the measured value. The differences likely resulted from 
the actual processes being more complicated than the models, including the coal combustion, raw meal decomposition, and nitrogen oxide reduction. Future studies will consider many simultaneous chemical reactions in the precalciner.

Table 8 Experimental and measured data

\begin{tabular}{|c|c|c|c|c|c|}
\hline \multicolumn{2}{|c|}{$\begin{array}{c}\text { Location } \\
\text { Flue gas } \\
\text { inlet }\end{array}$} & $\begin{array}{c}\text { Tertiary } \\
\text { air inlet }\end{array}$ & $\begin{array}{c}\text { Coal } \\
\text { inlet }\end{array}$ & Outlet \\
\hline \multirow{3}{*}{$\Delta p(\mathrm{~Pa})$} & Experiment & 0 & 300 & 100 & 550 \\
\cline { 2 - 6 } & measured & 0 & 255.93 & 85.74 & 472.91 \\
\cline { 2 - 6 } & Deviation & - & $14.69 \%$ & $14.26 \%$ & $14.02 \%$ \\
\hline \multirow{3}{*}{$T(\mathrm{~K})$} & Experiment & 1350 & 1190 & 311 & 1320 \\
\cline { 2 - 6 } & measured & 1350 & 1190 & 311 & 1600 \\
\cline { 2 - 6 } & Deviation & - & - & - & $17.5 \%$ \\
\hline
\end{tabular}

\section{RESULTS AND DISCUSSION}

The gas flow field, gas-solid two-phase flow field, and pulverized coal combustion process are analyzed in this section. The gas flow field is related to the two-phase flow and combustion process in the precalciner because that raw meal and coal particles are carried by the gas stream. The flow and diffusion of the solid particles in the gas-solid two-phase flow field also affects the pulverized coal combustion.

\subsection{Gas Flow Field}

The velocity distributions in the gaseous phase at two vertical planes are shown in Fig. 5(a). The flue gas flows into the precalciner from the bottom before passing upward through the neck. The tertiary air enters from the side near the bottom and flows in the positive $\mathrm{x}$ direction with a high initial velocity. The coal spreading air enters from all four sides just above the tertiary air. Due to low flow rate, the coal spreading air has only a minor impact on the overall flow field.

The velocity distributions on different cross sections are shown in Fig. 5(b). The inlet tertiary air creates a high speed zone at the bottom of the precalciner, with velocities up to $23 \mathrm{~m} / \mathrm{s}$. The pulverized coal and raw meal inlets can be seen in the slice just above the tertiary air duct. Hence, the coal and materials are quickly mixed by the high speed air flow. This mixing is conducive to rapid burning and decomposition of the pulverized coal and raw meal. The velocity decreases as the gas rises before increasing at the neck due to the reduced cross-sectional area and then decreases again in the top section. The average velocity at the precalciner outlet is $15.6 \mathrm{~m} / \mathrm{s}$. The slow velocity in the lower and upper sections increases the residence time in the precalciner to provide adequate time for the chemical reactions. The tertiary air flow makes the velocity distribution asymmetric which leads to a nonuniform solid particle distribution and affects the reaction stability in the precalciner.

Figure 6 shows the velocity vectors on cross sections at various heights $(y=2.00 \mathrm{~m}$ in the lower cone, $\mathrm{y}=3.14 \mathrm{~m}$ at the tertiary air entrance, $y=6.22 \mathrm{~m}$ at the raw meal entrance, $\mathrm{y}=8.00 \mathrm{~m}$ at the middle part of the lower section, $y=11.89 \mathrm{~m}$ in the middle neck and $\mathrm{y}=17.72 \mathrm{~m}$ in the middle part of the upper section). Each section has vortices except for $\mathrm{y}=2 \mathrm{~m}$ where the flue gas sprays upward and is unaffected by the tertiary air. Since the tertiary air flows radially inward, the vortices begin to appear at $y=3.143 \mathrm{~m}$ as the tertiary air enters the precalciner. The vortices increase the gas mixing and extend the residence time in the precalciner, increasing the effective precalciner volume and improving the fuel burning and material decomposition rates.

The streamlines inside the precalciner are shown in Fig. 7. The left image shows only the streamlines from the flue gas while the middle image shows only the streamlines from the tertiary air. Consistent with the results shown in Fig. 6, the flue gas can be seen flowing vertically into the precalciner from the bottom before beginning to spiral upward as the tertiary air stream enters the precalciner. Due to the different initial velocities, the tertiary air spirals closer to the wall, while the gas stream remains closer to the central axis of the precalciner. The streamlines from the coal spreading air are shown in the right image. The coal spreading air spirals upward which improves diffusion of the pulverized coal.
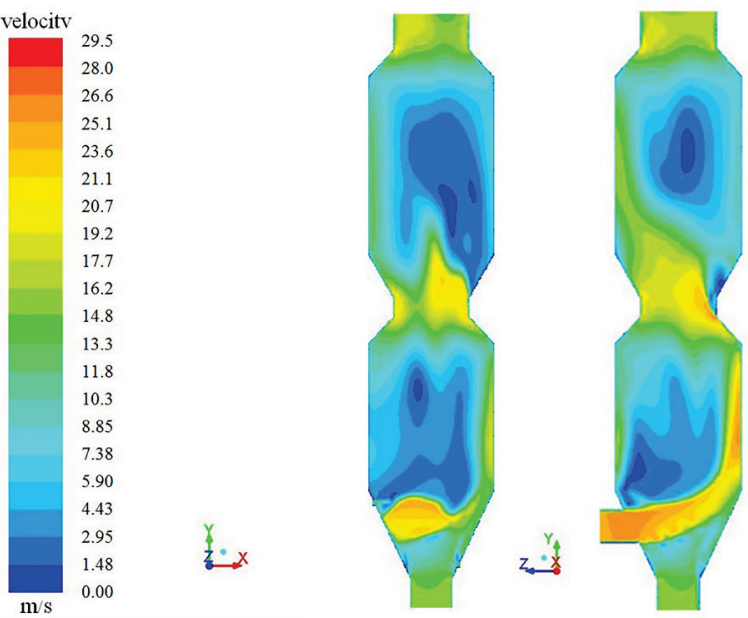

(a) Velocity distributions on the $\mathrm{z}=0$ and $\mathrm{x}=0$ planes

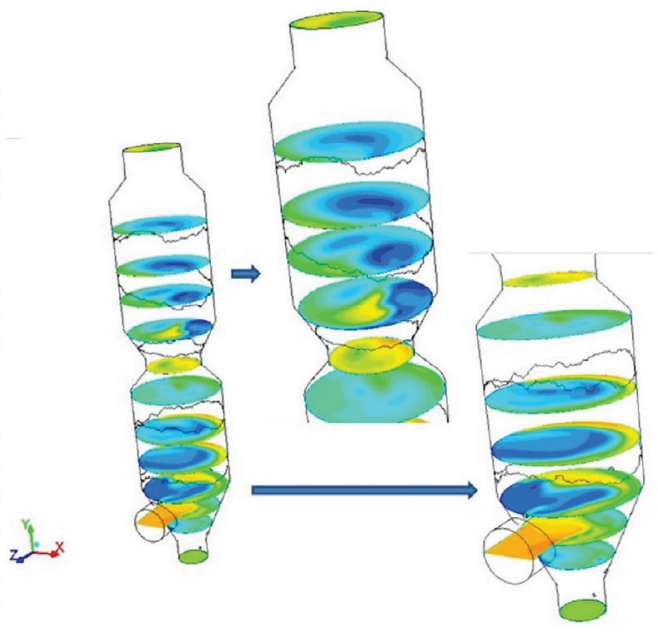

(b) Velocity distributions on various cross sections Fig. 5 Velocity distributions

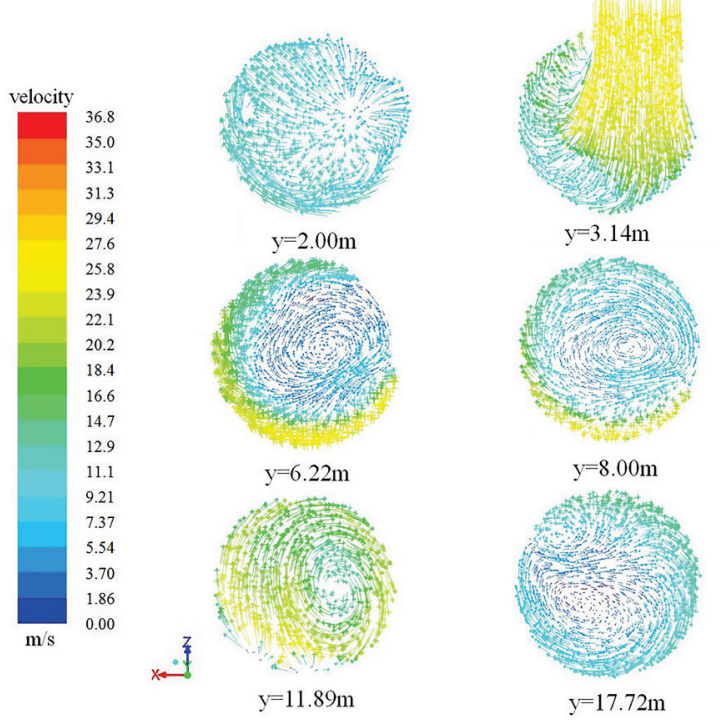

Fig. 6 Velocity vector distributions 

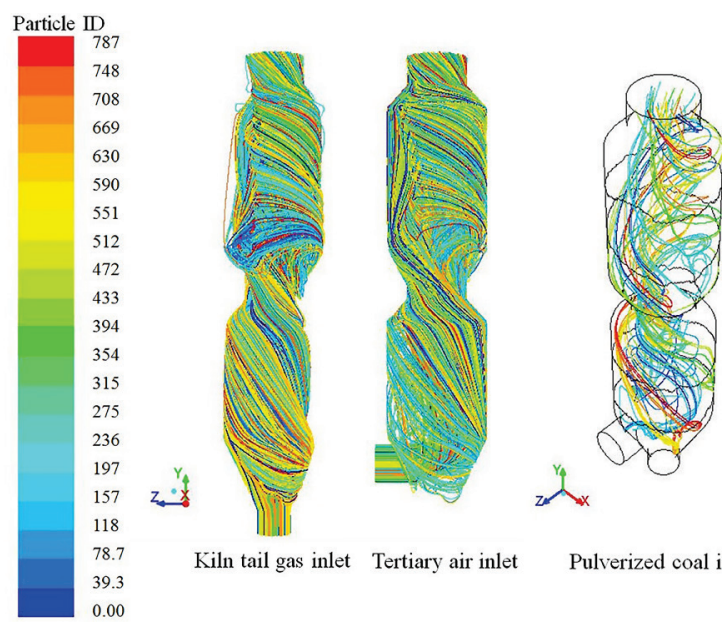

Pulverized coal inlets

Fig. 7 Streamlines

\subsection{Gas-Solid Two-Phase Flow Field}

The trajectories of the raw meal particles in time in the precalciner are shown in Fig. 8. The raw meal particles flow into furnace and are well dispersed. The maximum residence time of the raw material particles in the precalciner is $11.9 \mathrm{~s}$.

The trajectories of the pulverized coal in the precalciner are shown in Fig. 9. The pulverized coal particles rapidly flow into and fill the furnace. The particles are well dispersed, which facilitates the coal mixing and combustion. The maximum residence time of the raw meal particles is a little longer than that of the pulverized coal particles. The longer residence time provides enough time for the meal decomposition.
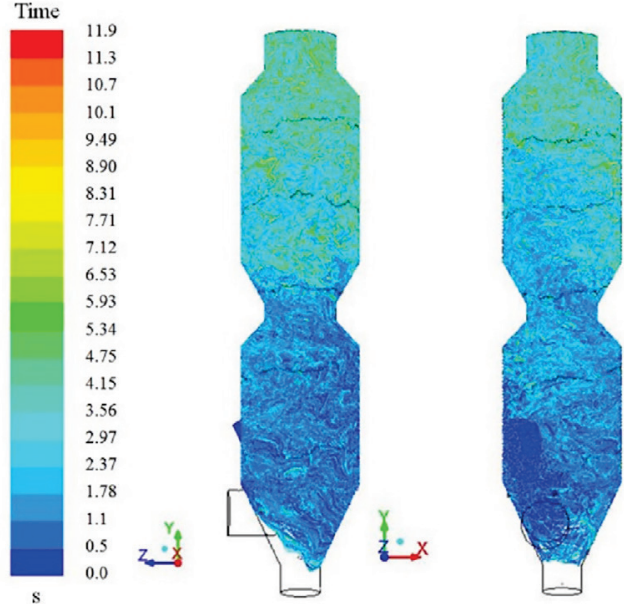

Fig. 8 Trajectories of the raw material particles
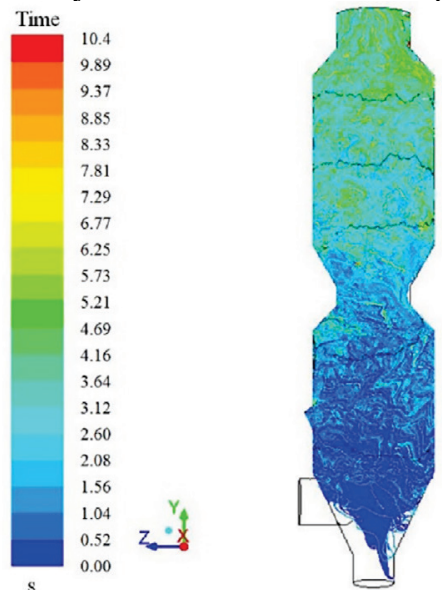

Fig. 9 Trajectories of the pulverized coal particles

\subsection{Pulverized Coal Combustion}

The temperature distributions in the precalciner are shown in Fig. 10. The flue gas inlet and tertiary air inlet temperatures are low, while the lower mixing chamber temperature is relatively high. The pulverized coal particles flow into the furnace above the tertiary air duct and burn quickly generating large amounts of heat. The raw material particles flow into the furnace from the high temperature region resulting in quick decomposition. However, there are some unfavorable high temperature regions in the precalciner. The average outlet temperature is near $1600 \mathrm{~K}$ which reduces the thermal efficiency and increases the wall adhesion with material blocking at the fifth level preheater inlet installed right behind the precalciner. The high-temperature region near the wall will damage the inner refractory wall and shorten the equipment lifetime. Some methods, such as changing the tertiary air inlet position and adjusting the tertiary air and pulverized coal flow rates may improve the temperature distribution.

The spatial concentration distributions of the reaction products in the precalciner are shown in Figs. 11 to 13. The $\mathrm{O}_{2}$ concentration is highest at the tertiary air entrance with mass fractions of $22 \%-23 \%$ as shown in Fig. 11. As the coal burns, oxygen is consumed and the oxygen concentration gradually decreases. In the upper section, the $\mathrm{O}_{2}$ mass fractions are only $1 \%$ to $5 \%$. The $\mathrm{CO}_{2}$ concentration shown in Fig. 12 has the opposite trend. The $\mathrm{CO}$ concentrations shown in Fig. 13 are high at the pulverized coal inlet as the coal begins to burn. As the CO flows upward and combines with $\mathrm{O}_{2}$, additional $\mathrm{CO}_{2}$ is created with the $\mathrm{CO}$ concentration approaching zero in the middle and upper sections of the precalciner. Thus, the $\mathrm{O}_{2}, \mathrm{CO}$ and $\mathrm{CO}_{2}$ concentration distributions indicate that the pulverized coal particles are well combusted for the given conditions.
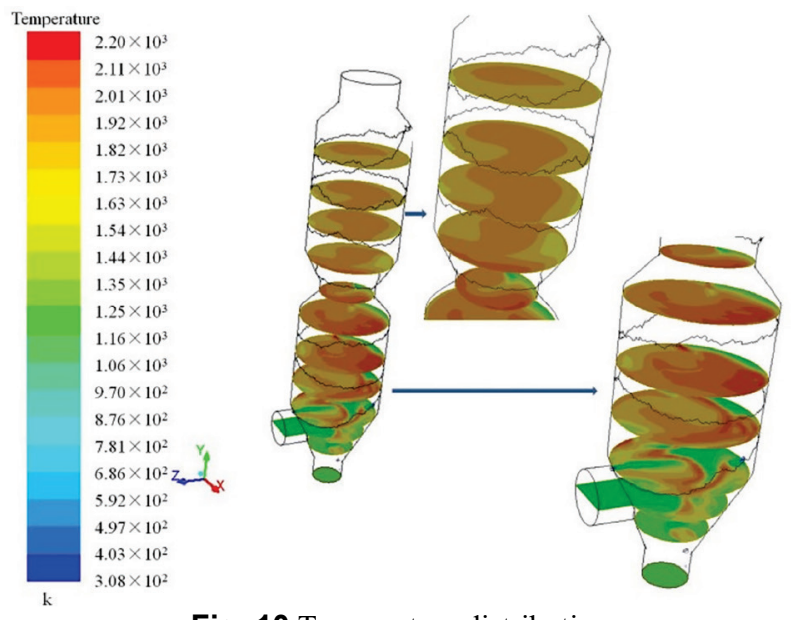

Fig. 10 Temperature distributions
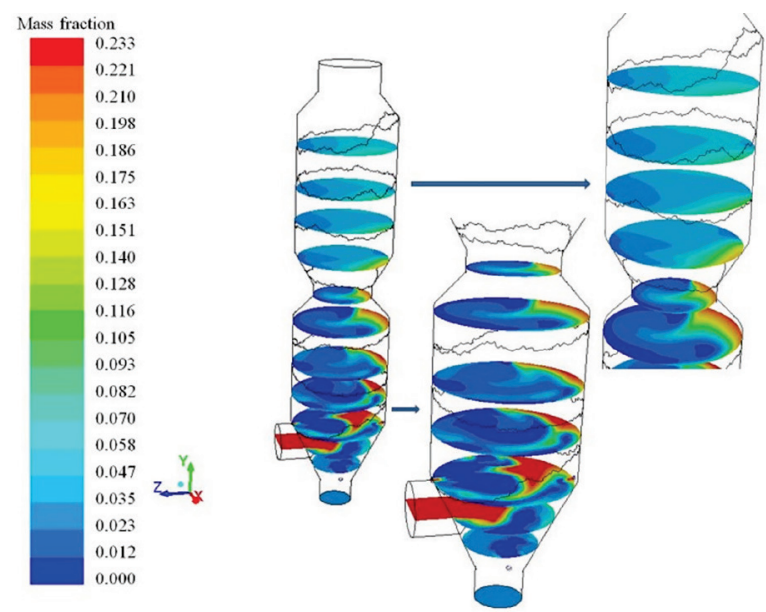

Fig. $11 \mathrm{O}_{2}$ concentration distribution 


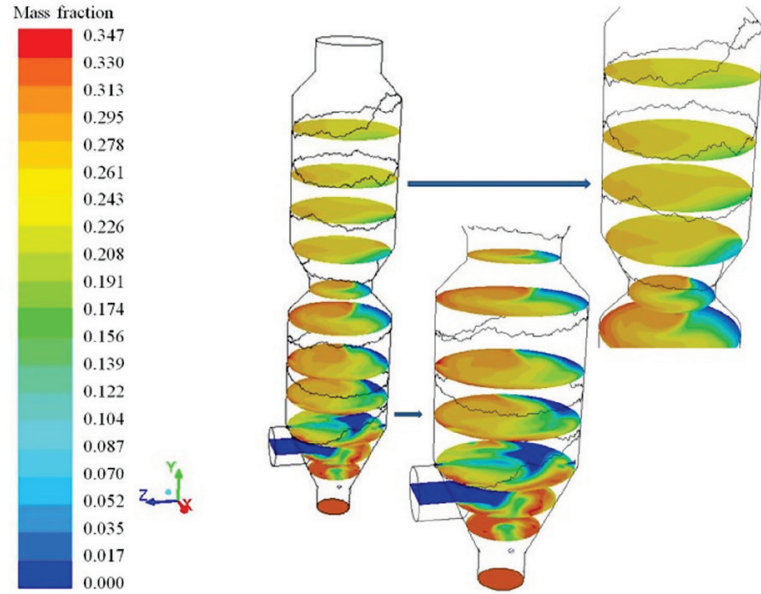

Fig. $12 \mathrm{CO}_{2}$ concentration distribution
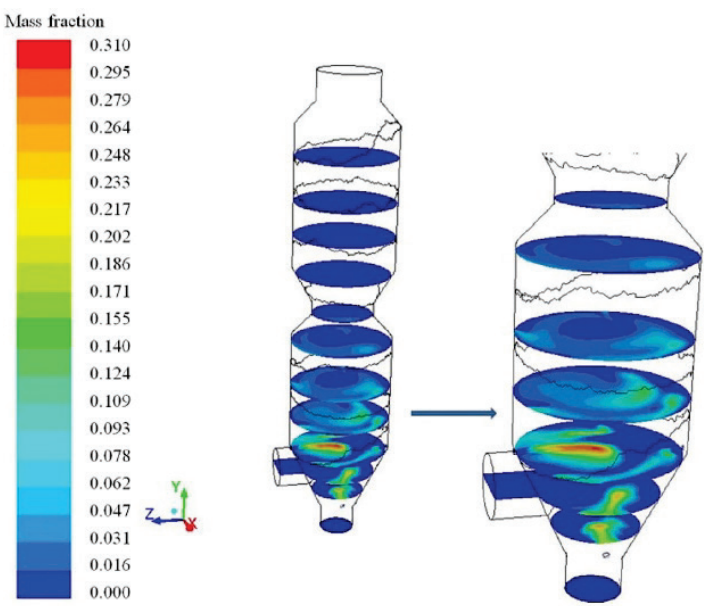

Fig. $13 \mathrm{CO}$ concentration distribution

\subsection{Precalciner optimization}

The precalciner structure was optimized to improve the velocity and temperature distributions in the precalciner. The optimized precalciner has two symmetrically positioned tertiary air ducts, whose eccentricities are the same as in the original model, as shown in Fig. 14. The tertiary air flow rate was not changed. Hence, the inner diameter of the tertiary air duct in the optimized precalciner is $1.414 \mathrm{~m}$ as calculated by Eq. (9).

$$
\pi\left(D_{1} / 2\right)^{2} \cdot u=2 \pi\left(D_{2} / 2\right)^{2} \cdot u
$$

where $D_{1}$ and $D_{2}$ are the inner diameters of the tertiary air duct in the original and optimized precalciners.

The fluid flow and pulverized coal combustion in the optimized precalciner were predicted using the same mathematical models and boundary conditions as for the original design. The velocity distribution, raw meal particle trajectories and temperature distribution are shown in Figs. 15 to 17 . The asymmetry of the velocity distribution is greatly improved as shown in Fig. 15. In addition, the maximum residence time of the raw meal particles is increased from $11.9 \mathrm{~s}$ to $15.8 \mathrm{~s}$ as shown in Fig. 16. The extended residence time improves the raw meal decomposition rate. Furthermore, the average precalciner outlet temperature is reduced from $1600 \mathrm{~K}$ to $1260 \mathrm{~K}$, which will reduce damage to the fifth preheater from excessively high temperatures.
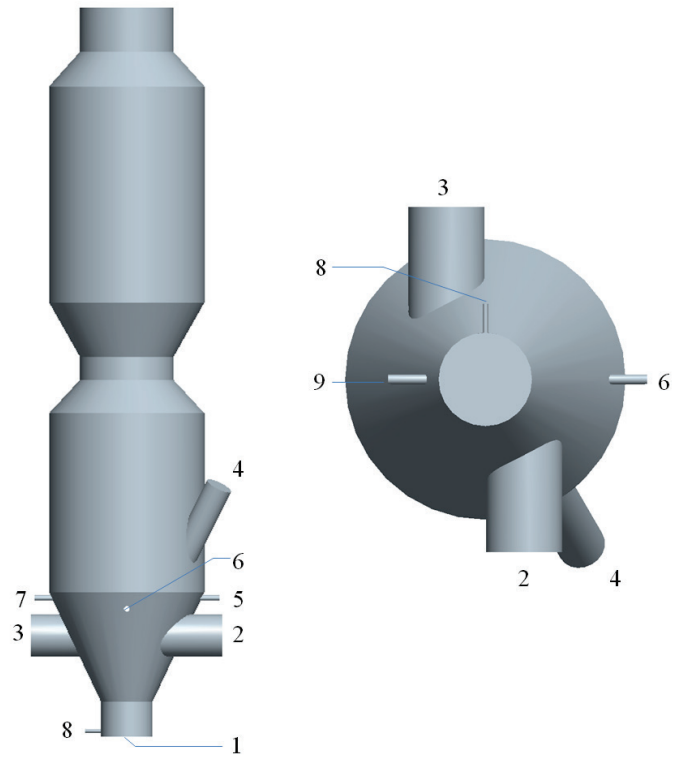

Fig. 14 Front and upward views of the optimized geometry (1 flue gas inlet; 2-3 tertiary air inlets; 4 raw meal inlet; 5-9 pulverized coal inlets a-e.)
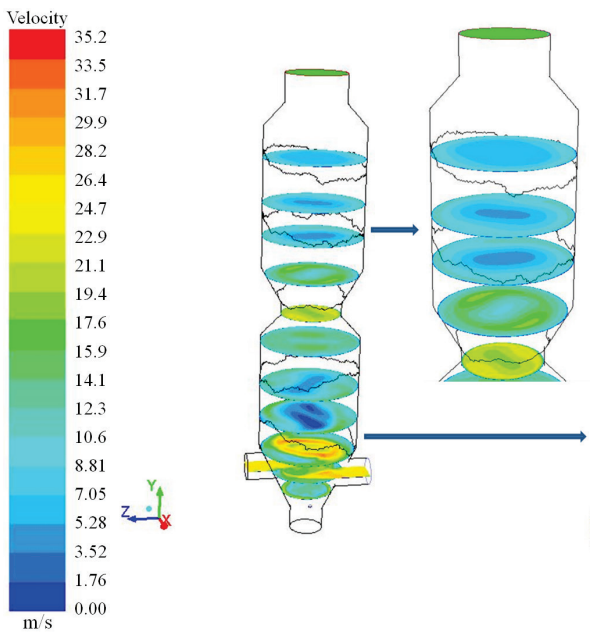

Fig. 15 Velocity distribution in the optimized precalciner
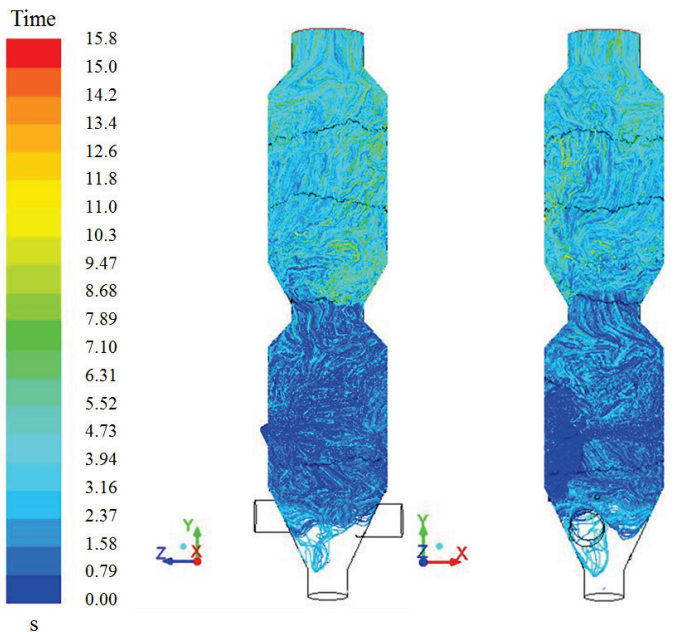

Fig. 16 Raw meal particle trajectories in the optimized precalciner 

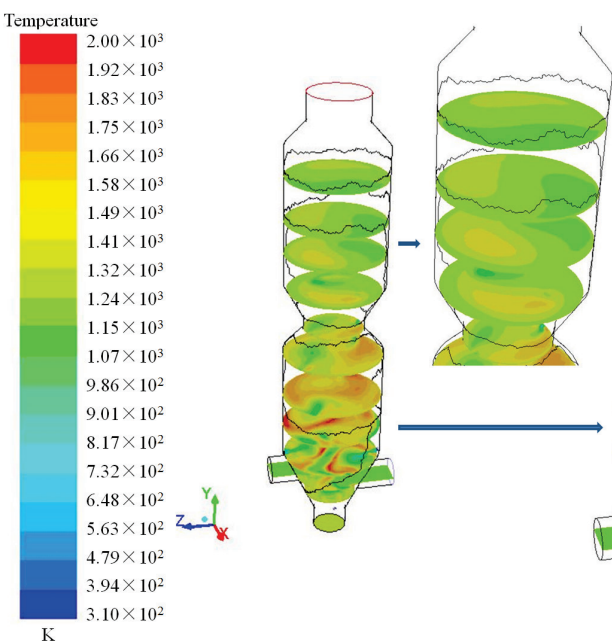

Fig. 17 Temperature distribution in the optimized precalciner

\section{CONCLUSIONS}

The flow parameters, gas composition and meal properties were measured in a precalciner in a cement production line. This experimental data was used to determine the boundary conditions for simulations and to validate a three-dimensional CFD model of a full scale industrial dual combustion and denitration precalciner. This model was used to simulate the complicated flow and thermal processes occurring in the precalciner. The model predicted the velocity, temperature, particle trajectories and gaseous production concentrations in the precalciner.

The calculated gas flow field showed that the gas spirals upward in the precalciner due to the horizontal, eccentric tertiary air inlets. Since the material particles are carried by the gas stream, the resulting vortices effectively disperse the particles and extend their resistance time in the furnace. The predicted raw meal and pulverized coal particle trajectories showed that the maximum residence time of the raw meal particles was a little longer than that of the pulverized coal particles. The calculated $\mathrm{O}_{2}$, $\mathrm{CO}$ and $\mathrm{CO}_{2}$ concentration distributions indicated that the coal particles are well disperses and fully combusted. The calculations showed that the precalciner outlet temperature is too high, which can damage the fifth preheater installed right behind the precalciner. Finally, the precalciner design was modified to improve the velocity and temperature distributions. The results can be used to improve future precalciner designs for industrial applications.

\section{ACKNOWLEDGEMENTS}

This work was supported by the Fundamental Research Funds of Shandong University and the National Basic Research Program of China (No.2013CB228305).

\section{NOMENCLATURE}

A speed of sound $\left(\mathrm{ms}^{-1}\right)$

$a_{k} \quad$ effective Prandtl number for $k$

$a_{\varepsilon} \quad$ inverse effective Prandtl number for $\varepsilon$

$D \quad$ inner diameter (m)

$G \quad$ dissipation of kinetic energy as turbulence

$k \quad$ turbulence kinetic energy $\left(\mathrm{m}^{2} \mathrm{~s}^{-2}\right)$

$p \quad$ pressure $(\mathrm{Pa})$

$\mathrm{Pr}_{\mathrm{t}} \quad$ turbulent Prandtl number

$q_{v} \quad$ volume flow rate $\left(\mathrm{m}^{-3} \mathrm{~h}^{-1}\right)$

$T \quad$ temperature (K)

$u \quad$ velocity $\left(\mathrm{ms}^{-1}\right)$

Greek Symbols

$$
\begin{array}{ll}
\rho & \text { density }\left(\mathrm{kgm}^{-3}\right) \\
\varepsilon & \text { rate of dissipation of } k\left(\mathrm{~m}^{2} \mathrm{~s}^{-3}\right) \\
\mu & \text { dynamic viscosity }(\mathrm{Pa} \mathrm{s})
\end{array}
$$

Subscripts

$b \quad$ buoyancy

$n \quad$ standard condition

$l \quad$ laminar

$t \quad$ turbulent

p particle

\section{Abbreviations}

CFD computational fluid dynamics

DD dual combustion and denitration

DPM discrete phase model

RNG renormalization-group

PDF probability density function

\section{REFERENCES}

Bashir, A., Awais, M. M., and Shamail, S., 2004, "CFD Based Combustion Modeling for Industrial Scale Combustors," Proceedings of 8th International Multitopic Conference, 547-552.

http://dx.doi.org/10.1109/INMIC.2004.1492941

Boesch, M. E., Koehler, A., and Hellweg, S., 2009, "Model for Cradleto-gate Life Cycle Assessment of Clinker Production," Environmental Science \& Technology, 43(19), 7578-7583.

http://dx.doi.org/10.1021/es900036e

Dam, K., 2002, "Modeling of In-line Low-NOx Calciners - a Parametric Study," Chemical Engineering Science, 57(5), 789-803. http://dx.doi.org/10.1016/S0009-2509(02)00003-9

Dou, H., Chen, Z., and Huang, J., 2007, "Numerical Study of Anthracite Combustion Mechanism in a 2000 t/d Precalciner," Computers \& Applied Chemistry, 24(12), 1599-1606. http://dx.doi.org/10.1016/S1872-2067(07)60020-5

Fan, W., Zhu, T., Sun, Y., and Lv, D., 2014, "Effects of Gas Compositions on $\mathrm{NO}_{\mathrm{x}}$ Reduction by Selective Non-catalytic Reduction with Ammonia in a Simulated Cement Precalciner Atmosphere," Chemosphere, 113, 182-187.

http://dx.doi.org/10.1016/j.chemosphere.2014.05.034

Fidaros, D. K., Baxevanou, C. A., Dritselis, C. D., and Vlachos, N. S., 2007, "Numerical Modelling of Flow and Transport Processes in a Calciner for Cement Production," Power Technology, 171(2), 81-95. http://dx.doi.org/10.1016/j.powtec.2006.09.011

Gentzis, T., Goodarzi, F., Koukouzas, C. N., and Foscolos, A. E., 1996, "Petrology, Mineralogy, and Geochemistry of Lignites from Crete. Greece," International Journal of Coal Geology, 30(1-2), 131-150. http://dx.doi.org/10.1016/0166-5162(95)00034-8

Huang, L., Lu, J., Xia, F., Li, W., and Ren, H., 2006, “3-D Mathematical Modeling of an In-line Swirl-spray Precalciner," Chemical Engineering and Processing, 45 (3), 204-213.

http://dx.doi.org/10.1016/i.cep.2005.09.001

Hu, Z., Lu, J., Huang, L., and Wang, S., 2006, "Numerical Simulation Study on Gas-solid Two-phase Flow in Pre-calciner," Communications in Nonlinear Science and Numerical Simulation, 11(3), 440-451. http://dx.doi.org/10.1016/j.cnsns.2004.07.004

Iliuta, I., Dam-Johansen, K., and Jensen, L. S., 2002, "Mathematical Modeling of an In-line Low-NO $\mathrm{N}_{\mathrm{x}}$ Calciner," Chemical Engineering Science, 57(5), 805-820.

http://dx.doi.org/10.1016/s0009-2509(01)00420-1 
Kolyfetis, E., and Vayenas, C.G., 1988, "Mathematical Modelling of Separate Line Precalciners (SLC)," Zement Kalk Gips, 41(11), 559-563.

Kupper, D., and Tiggesbaeumker, P., 1983, "The Calcination Behavior of Cement Raw Meals," Zement Kalk Gips, 36(5), 275-280.

Liu, F., Marc, R., and Wang, S., 1995, "Energy Efficiency of China's Cement Industry," Energy, 20(7), 669-681.

http://dx.doi.org/10.1016/0360-5442(95)00002-X

Liu, H., Liu, W., and Zheng, J., 2004, "Numerical Study of Gas-solid Flow in a Precalciner Using Kinetic Theory of Granular Flow," Chemical Engineering Journal, 102(2), 151-160.

http://dx.doi.org/10.1016/j.cej.2004.03.004

Lv, G., Lu, J., Cai, L., Xie, X., and Liu, Z., 2011, "Experimental Study on the Dynamic Process of NO Reduction in a Precalciner," Industrial \& Engineering Chemistry Research, 50(8), 4366-4372. http://dx.doi.org/10.1021/ie102118c

Ma, X., Yang, M., and Zhang, Y., 2016, "Analysis of Combustion Mechanism and Combustion Optimization of a 300 MW Pulverized Coal Boiler," Frontiers in Heat and Mass Transfer, 7(36), 1-8. http://dx.doi.org/10.5098/hmt.7.36

Mei, S., Xie, J., Chen, X., He, F., and Jin, M., 2017, "Numerical Simulation of the Complex Thermal Processes in a Vortexing Precalciner," Applied Thermal Engineering, 125, 652-661. http://dx.doi.org/10.1016/j.applthermaleng.2017.07.041

Orszag, S. A., Yakhot, V., Flannery, W.S. Boysan, F., Choudhury, D., Maruzewski, J. and Patel, B., 1993, "Renormalization Group Modeling and Turbulence Simulations," Proceedings of International Conference on Near-Wall Turbulent Flows, Tempe, Arizona.
Qi, X., Yang, M., and Zhang, Y., 2017, "Numerical Analysis of NOx Production under the Air Staged Combustion," Frontiers in Heat and Mass Transfer, 8(3), 1-8.

http://dx.doi.org/10.5098/hmt.8.3

Rosemann, H., 1986, "Energy Transfer in Precalcining Installations," Zement Kalk Gips, 39(2), 84-86.

Sivathanu, Y. R., and Faeth, G. M., 1990, "Generalized State Relationships for Scalar Properties in Non-premixed Hydrocarbon/ air Flames," Combustion and Flame, 82 (2), 211-230. http://dx.doi.org/10.1016/0010-2180(90)90099-D

Veras, C.A.G., Saastamoinen, J. J., Carvalho, J., and Aho, M. J., 1999, "Overlapping of the Devolatilization and Char Combustion Stages in the Burning of Coal Particles," Combustion and Flame, 161(4), 567-579. http://dx.doi.org/10.1016/s0010-2180(98)00064-9

Zhang, S., Wei, M., and Yang, H., 2018, "Study on Flow and Temperature Behavior of Catalytic Honeycomb Monolith Combustion Furnace of Natural Gas to Properties of Glazed Tiles," Frontiers in Heat and Mass Transfer, 11(20), 1-5.

http://dx.doi.org/10.5098/hmt.11.20

Zheng, J., Liu, W., Zhao, Y., Zhao, X., and Lu, H., 2005, "Numerical Simulations of Hydrodynamics for Gas Solid Two-phase Flow in Calciners (in Chinese)," Journal of the Chinese Ceramic Society, 33(7), 853-858.

http://dx.doi.org/10.3321/j.issn:0454-5648.2005.07.012

Zheng, J., Lu, H., Sun, X., He, Y., Ding, J., and Wang, S., 2005, "Hydrodynamic Modeling of Gas-particle Flows in D-D Calciners," Industrial \& Engineering Chemistry Research, 44(9), 3033-3041. http://dx.doi.org/10.1021/ie040168j 